ISSN: 2224-0616

Int. J. Agril. Res. Innov. Tech. 10(1): 22-27, June 2020

DOI: https://doi.org/10.3329/ijarit.v10i1.48090
OPEN O ACcEss

Available online at https://ijarit.webs.com https://www.banglajol.info/index.php/IJARIT

\title{
Effect of row arrangement of common bean with maize intercropping on yield and economic benefit of component crops under Gimbo and Guraferda, Kaffa and Bench Maji zones, South Ethiopia
}

\author{
M. Mogiso ${ }^{1^{*}}$ and N. Nazib ${ }^{2}$ \\ Received 19 March 2020, Revised 17 April 2020, Accepted 20 June 2020, Published online 30 June 2020
}

\begin{abstract}
A B S T R A C T
The yield advantage obtained due to intercropping is attributed to a better use of resources by crops grown in combinations, as compared to sole stands. Field experiment conducted at Gimbo and Guraferda during 2017 and 2018 cropping seasons in order to determine the appropriate intercropping row arrangement on maize-common bean yield and economic advantages of the cropping system. Maize variety $\mathrm{BH}-54 \mathrm{O}$ and common bean variety Hawassa dume were used as test crop. The experiment used four treatments (sole maize, sole common bean, 1:1 maizecommon bean and 1:2 maize-common bean intercropping) arranged in a randomized complete block design with four replications. Grain yield of the component crops were significantly varied by locations. The highest maize yield was recorded at Guraferda than Gimbo; whereas, common bean yielded better at Guraferda than at Gimbo. The combined mean grain yield of maize and common bean was significantly $(\mathrm{p}<0.05)$ higher for sole stands than intercropping. The highest yield of 6545.7 and $5570.6 \mathrm{~kg} \mathrm{ha}^{-1}$ was obtained from sole maize at Guraferda and Gimbo locations, respectively. On the other hand, the highest yield of 3407.2 and $2638.0 \mathrm{~kg} \mathrm{ha}^{-1}$ was obtained from growing sole common bean at Gimbo and Guraferda locations, respectively. The yield obtained from 1:1 maize-common bean intercropping was statistically same with sole maize yield at Guraferda. The highest LER of 1.62 and 1.52 with MAI of 15,268.05 and 13.695.90 ETB ha $^{-1}$ obtained from 1:1 maize-common bean intercropping at Guraferda and Gimbo locations, respectively. Generally, growing 1:1 maize-common bean intercropping found to be more productive and economically profitable than others. Hence, a one row common bean intercropped between the two rows of maize can be recommended in the lowlands of Gimbo and Guraferda areas.
\end{abstract}

Keywords: Intercropping advantage, Land equivalent ratio, Monitory advantage index.

Southern Agricultural Research Institute (SARI), Bonga Agricultural Research Center, 101 Bonga, Ethiopia.

*Corresponding author's email: mogisog22@gmail.com (M. Mogiso)

Cite this article as: Mogiso, M. and Nazib, N. 2020. Effect of row arrangement of common bean with maize intercropping on yield and economic benefit of component crops under Gimbo and Guraferda, Kaffa and Bench Maji zones, South Ethiopia. Int. J. Agril. Res. Innov. Tech. 10(1): 22-27. https://doi.org/10.3329/ijarit.v10i1.48090

\section{Introduction}

Intercropping is one of the commonly used cropping practices in most tropical areas in Africa. It is the growing of two or more crop species simultaneously in the same land during the growing season (Lithourgidis et al., 2011). Shortage of the farm land due to population pressure forced to explore new ways to intensify production and productivity per unit area of land (Usmanikhail et al., 2012). Nasri et al. (2014) stated that the benefit of intercropping over sole cropping in terms of production per unit area. It is an attractive strategy to increase the productivity and land use efficiency (Seran and Brintha, 2010). Cereal-legume intercropping is the most commonly used practice by smallholder farmers in developing countries because of its environmental as well as economic advantages (Willey, 1979). It is also important for better use of resources, improvement of soil fertility, soil conservation and reduction of risks and suppression of weed infestation (Emam, 2003). However, the advantage of intercropping is obtained when correspondent species has differences in crop architecture, maturity time, nutrient use to optimize the use of natural resources and environmental factors when cropped together (Nurbakhsh et al., 2013). 
Maize and common bean are the major food crops among cereals and pulses in mid and low land areas of Ethiopia. Maize is the most important cereal crop after wheat and rice with regards in production area in the world (Osagie and Eka, 1998) and fourth after teff, barley and sorghum in Ethiopia (IFPRI, 2010). In view of its importance in terms of wide adaptation, total production and productivity, maize has been selected as one of the high priority crops to feed the increasing human population of Ethiopia. On the other hand, common bean is also a major food crop particularly in Southern and Eastern parts of Ethiopia and considered as the main cash crop and protein source for farmers (EPPA, 2004; Negash, 2007). Most of the research findings of the previous studies proved that the productivity of intercropping over sole cropping (Lithourgidis et al., 2011; Gomez and Gomez, 1983).

Intercropping has an advantage and often provides higher economic benefit than mono cropping (Amanullah et al., 2006). Intercropping productivity and economic benefit was determined by using different evaluating indices. Land equivalent ratio (LER) and monitory advantage index (MAI) are the commonly used indices adopted in intercropping to evaluate intercropping advantages. LER is an indicator to determine the efficiency of intercropping (Kurata, 1986). The value of LER greater than one indicates that the greater efficiency of land utilization in intercropping due to greater efficiency of resource utilization in intercropping (Seran and Brintha, 2010).

Maize and common bean has been considered as the best component crops in intercropping system (Willey and Osiru, 1972) because of its suitability to the cropping system. In fact, mono cropping of maize is the common farmer's practice in the low lands of Gimbo and Guraferda areas. Du to this, the productivity of the crop has been declined substantially. On the other hand, the demand for food is rapidly increasing and the availability of land for agriculture is shrinking due to population pressure and urbanization. Under this situation, one of the most important strategies is intensification of crop production and increasing the productivity per unit area of land. Intercropping is an attractive strategy to increase crop productivity and land use efficiency (Seran and Brintha, 2010). However, not much is known about the importance of intercropping in terms of land use efficiency and economic benefit. In addition, there is no research activity conducted regarding intercropping of common bean with maize on yield and economic benefits of the cropping system in the study areas. Therefore, this study was undertaken to determine the appropriate intercropping row ratio of common bean with maize for better land productivity and economic benefit.

\section{Materials and Methods}

\section{Description of the experimental site}

The experiment was conducted for two years in Kaffa and Bench Maji Zones. The experimental site was located at $07^{\circ} 24^{\prime} \mathrm{N}$ latitude, $36^{\circ} 26^{\prime} \mathrm{E}$ longitude and an altitude of 1233 meter above sea level (Shomba Sheka site, Gimbo district) and $06^{\circ}$ $50^{\prime} \mathrm{N}$ latitude, $35^{\circ} 15^{\prime} \mathrm{E}$ longitude and an altitude of 1133 meter above sea level (Otuwa site, Guraferda district).

\section{Experimental materials}

Maize variety $\mathrm{BH}-540$ and Common bean variety Hawassa dume were used for this study. These varieties were the most adopted and high yielding varieties in the location.

\section{Agronomic practices}

The experimental field was ploughed, leveled properly. Sowing was done by putting the seeds in rows at the space of 25 and $10 \mathrm{~cm}$ for maize and common bean, respectively. NPS fertilizer (NPS 19:38:5) was applied at the rate of $100 \mathrm{~kg} \mathrm{ha}^{-1}$ during sowing. Other than the treatment weeding, harrowing and fertilizer application were carried out uniformly in all experimental plots.

\section{Treatments and experimental design}

Inclusion of common bean by constant maize population was used in the study. The treatments consisted of sole maize, sole common bean, 1:1 and 1:2 row ratios of maize-common bean intercropping. The experiment was arranged in randomized complete block design with four replications. Each experimental plot area consisted of $4.8 \times 5.0 \mathrm{~m}$ length $\left(24 \mathrm{~m}^{2}\right)$ and $16 \mathrm{~m}^{2}$ was used as a net plot area. The distance between plots and blocks were 1.0 and $1.5 \mathrm{~m}$, respectively. Plants from the internal rows of net plot area were used for data collection.

\section{Data collection}

Grain yield ( $\left.k g h a^{-1}\right)$ : Grain yield of the component crops were measured from the net plot area and expressed as $\mathrm{kg} \mathrm{ha}^{-1}$. The grain yield was adjusted to recommended moisture content of $12.5 \%$ for maize and $10 \%$ for common bean. Finally, the data was subjected to the statistical analysis.

Land equivalent ratio ( $L E R$ ): is the relative area required by sole crops to produce the same yield as intercrop. The LER values were computed using the following formula described by Willey (Willey, 1979; Willey and Osiru, 1972).

Where:

$$
L E R=\frac{Y_{\mathrm{ab}}}{Y_{\mathrm{aa}}}+\frac{Y_{\mathrm{ba}}}{Y_{\mathrm{bb}}}
$$

$\mathrm{Y}_{\mathrm{ab}}=$ Yield of maize when intercropped with common bean; $\mathrm{Y}_{\mathrm{ba}}=$ Yield of common bean when intercropped with maize; $\mathrm{Y}_{\mathrm{aa}}=$ Yield of sole sown maize; $\mathrm{Y}_{\mathrm{bb}}=$ Yield of sole sown common bean. 
Monetary advantage index (MAI): The yield of intercropping and sole cropping system and their economic return in terms of monetary value were evaluated to find out whether maize yield and added common bean yield are profitable or not. The lowest average price at Gimbo and Guraferda districts after harvest of crops was 5 birr kg-1 for maize and 6 birr $\mathrm{kg}^{-1}$ for common bean in that order. The higher the MAI value the more profitable is the cropping system (Mahapatra, 2011).

Where,

$$
M A I=\left(P_{\mathrm{ab}}+P_{\mathrm{ba}}\right) * \frac{L E R-1}{L E R}
$$

$\mathrm{P}_{\mathrm{ab}}=\mathrm{P}_{\mathrm{a}} \times \mathrm{Y}_{\mathrm{ab}} ; \mathrm{P}_{\mathrm{ba}}=\mathrm{P}_{\mathrm{b}} \times \mathrm{Y}_{\mathrm{ba}} ; \mathrm{P}_{\mathrm{a}}=$ Price of maize; $\mathrm{P}_{\mathrm{b}}$ $=$ Price of common bean.

\section{Statistical analysis}

The collected data were subjected to statistical analysis using PROC GLM procedures in SAS version 9.3 (SAS institute, 2002-2010). Variations between the treatment means were compared using least significant difference (LSD) at $5 \%$ probability level.

\section{Results and Discussion}

Combined analysis of variance showed significant difference $(\mathrm{p}<0.05)$ among the treatments for grain yield. The significant difference was also observed between years for grain yield (Table 1). Among years the higher grain yield was recorded in 2017 than 2018 (Table 2). This might be due to the variations in weather conditions of both years.

Table 1. Mean square values for the component crops.

\begin{tabular}{|c|c|c|c|c|c|}
\hline \multirow[t]{3}{*}{ Source of variation } & \multirow[t]{3}{*}{ DF } & \multicolumn{4}{|c|}{ Mean Squares } \\
\hline & & \multicolumn{2}{|c|}{ Maize yield } & \multicolumn{2}{|c|}{ Common bean yield } \\
\hline & & Gojeb & Guraferda & Gojeb & Guraferda \\
\hline Year & 1 & $9014361.60^{* *}$ & $23846845.1^{* * *}$ & 886391.8* & $651.200 \mathrm{NS}$ \\
\hline Replication (year) & 6 & 217890.10 & 112234.6 & 99285.4 & 91278.500 \\
\hline Treatment & 2 & $1801238.90^{*}$ & $300301.4^{*}$ & $4685988.4^{* *}$ & $2936259.000^{* *}$ \\
\hline year*treatment & 2 & $54052.10 \mathrm{NS}$ & $30947.4 \mathrm{NS}$ & $53445.7 \mathrm{NS}$ & $157096.900 \mathrm{NS}$ \\
\hline Error & 12 & 490855.26 & 237627.0 & 125263.0 & 93258.674 \\
\hline Total & 23 & & & & \\
\hline
\end{tabular}

** = highly significant, ${ }^{*}=$ significant and NS = non-significant at LSD (5\%) probability level.

Effect of intercropping on grain yield of the component crops

The statistical analysis of the data from field experiment revealed that there were significant variations between intercropping and sole cropping on grain yield of maize and common bean. The grain yields of the component crops under sole cropping were significantly higher than those under intercropping.

\section{Maize yield}

The result obtained from field experiment indicated that intercropping of common bean with maize had significant $(\mathrm{P}<0.05)$ effect on grain yield of maize. The highest maize grain yield of $5570.6 \mathrm{~kg} \mathrm{ha}^{-1}$ was produced in sole cropping when compared to the intercropping systems at Gimbo location. The lowest mean maize grain yield was obtained at 1:2 maizecommon bean rows (4626.5 $\mathrm{kg} \mathrm{ha}^{-1}$ ), which was not significantly lower than 1:1 maize-common bean intercropping (5015.4 $\mathrm{kg} \mathrm{ha}^{-1}$ ) (Table 2). Intercropping of common bean with maize had significant effect on yield of maize. The highest grain yield of sole cropping as compared to intercropping was due to the result of competition between the component crops for natural resources. This result is similar with the previous findings of Tsubo et al. (2004). In contrast, Takim (2012) reported that the maize grain yield increased when maize intercropped with cowpea. On the other hand, At Guraferda the sole cropped maize and 1:1 maize-common bean intercropping was statistically same. The inclusion of one row common bean in between maize row did not affect grain yield of maize. This might be due to less competition between the component crops for nutrients. The highest maize grain yield was recorded for sole cropped maize (6545.7 $\mathrm{kg} \mathrm{ha}^{-1}$ ) and 1:1 maize-common bean intercropping (6353.9 $\left.\mathrm{kg} \mathrm{ha}^{-1}\right)$ at Guraferda. However, the lowest grain yield of $6158.2 \mathrm{~kg} \mathrm{ha}^{-1}$ was obtained from 1:2 maize-common bean intercropping. Between the two locations, the highest grain yield of maize was obtained from Guraferda. It might be due to the variations in soil characteristics and environmental conditions of both locations. 
Table 2. Mean grain yield $\left(\mathrm{kg} \mathrm{ha}^{-1}\right)$ of maize when intercropped with common bean.

\begin{tabular}{|c|c|c|c|c|c|c|}
\hline \multirow[t]{3}{*}{ Treatments } & \multicolumn{4}{|c|}{ Separate analysis } & \multicolumn{2}{|c|}{ Combined analysis } \\
\hline & \multicolumn{2}{|c|}{ Gimbo } & \multicolumn{2}{|c|}{ Guraferda } & \multirow[t]{2}{*}{ Gimbo } & \multirow[t]{2}{*}{ Guraferda } \\
\hline & 2017 & 2018 & 2017 & 2018 & & \\
\hline Sole bean & - & - & - & - & - & - \\
\hline Sole maize & 6171.9 & 4669.3 & 7587.3 & 5504.0 & 5570.6 & 6545.7 \\
\hline 1M:1B & 5715.6 & 4315.1 & 7376.8 & 5330.9 & $5015 \cdot 4$ & 6353.9 \\
\hline 1M:2B & 5163.0 & 4089.4 & 7084.0 & 5232.4 & 4626.5 & 6158.2 \\
\hline Mean & 5683.7 & 4458.0 & 7349.4 & 5355.8 & 5070.8 & 6352.6 \\
\hline LSD (5\%) & 1637.1 & 508.6 & 872.6 & 813.2 & 500.2 & 378.5 \\
\hline CV (\%) & 16.7 & 6.6 & 6.9 & 8.8 & 13.8 & 7.7 \\
\hline
\end{tabular}

$1 M: 1 B=$ one row of maize intercropped with one row of common bean; $1 M: 2 B=$ one row maize intercropped with two rows of common bean.

\section{Common bean yield}

There was significant variation observed between the locations. Based on the data common bean gave better yield at Gimbo than Guraferda location. It might be due to the conduciveness of weather condition as well as soil characteristics for the growth and development of common bean in the location.

Intercropping of maize with common bean significantly affect common bean yield $(\mathrm{P}<0.05)$. The highest grain yield of $3407.2 \mathrm{~kg} \mathrm{ha}^{-1}$ was produced from sole cropped common bean at Gimbo. The lowest grain yield was obtained from
1:2 (2056.9 kg ha-1) and 1:1 (2107.8 $\mathrm{kg} \mathrm{ha}^{-1}$ ) maize-common bean intercropping, respectively. At Guraferda, the highest grain yield of $2638.0 \mathrm{~kg}$ $\mathrm{ha}^{-1}$ of common bean was recorded for sole cropped common bean. The lowest common bean yield 1497.2 and $1714.1 \mathrm{~kg} \mathrm{ha}^{-1}$ was recorded for 1:2 and 1:1 maize-common bean intercropping, respectively. The highest grain yield of common bean obtained from sole cropping as compared to intercropping due to the fact that more number of plant populations per unit area. Similar result was reported earlier by Tamiru (2014).

Table 3. Mean grain yield $\left(\mathrm{kg} \mathrm{ha}^{-1}\right)$ of common bean when intercropped with maize.

\begin{tabular}{|lcccccc|}
\hline & \multicolumn{3}{c}{ Treatments } & \multicolumn{2}{c}{ Gimbo } & \multicolumn{2}{c}{ Gurate analysis } & \multicolumn{2}{c|}{ Gombined analysis } \\
\cline { 2 - 5 } & 2017 & 2018 & 2017 & 2018 & & \\
\hline Sole bean & 3309.4 & 3505.0 & 2753.8 & 2522.3 & 3407.2 & 2638.0 \\
\hline Sole maize & - & - & - & - & - & - \\
\hline 1M:1B & 1868.7 & 2346.9 & 1766.4 & 1661.9 & 2107.8 & 1714.1 \\
\hline 1M:2B & 1817.2 & 2296.5 & 1344.8 & 1649.6 & 2056.9 & 1497.2 \\
\hline Mean & 2331.8 & 2716.1 & 1955.0 & 1944.6 & 2524.0 & 1949.8 \\
\hline LSD (5\%) & 670.7 & 547.9 & 547.4 & 508.7 & 497.4 & 852.7 \\
\hline CV (\%) & 16.6 & 11.7 & 16.2 & 15.1 & 14.0 & 15.7 \\
\hline
\end{tabular}

$1 M: 1 B=$ one row of maize intercropped with one row of common bean; $1 M: 2 B=$ one row maize intercropped with two rows of common bean.

\section{Yield advantages of the cropping system}

One of the main objectives of intercropping is increasing productivity per unit area. The productivity and benefit of the maize-common bean intercropping were evaluated by using land equivalent ratio (LER) and monitory advantage index (MAI), respectively. Land equivalent ratio (LER) is used for estimating advantages or disadvantages of intercropping over sole cropping system (Dhima et al., 2007). Based on the result, the intercropping treatments had higher LER than monoculture, which indicated the superiority of intercropping over sole cropping. Likewise, the highest economic advantage was also recorded from intercropping as compared to sole cropping in both locations (Table 4 and 5). In terms of productivity and economic benefit per unit area, the highest yield was recorded from Guraferda location. Growing 1:1 maize-common bean intercropping had the highest land use efficiency and economic benefit than growing 1:2 maize-common bean intercropping at both locations. The higher LER of 1.62 and 1.52 was recorded from 1:1 maize-common bean intercropping at Guraferda and Gimbo locations, respectively. However, the lower LER was recorded from 1:2 maize-common bean intercropping at Guraferda (1.50) and Gimbo (1.43) (Table 4). It indicates that the growing of one row of maize with one rows of common bean gave a $62 \%$ and $52 \%$ yield advantage than growing maize or common bean independently as sole crop. This result is consistent with the findings of Tsubo et al. (2004). Higher LER in intercropping treatments compared to sole cropping is attributed to better utilization of 
resources (Willey, 1979; Fujita and Ofosu-Budu, 1996). In addition, several researchers reported the higher LER due to intercropping of legumes with maize, sorghum, and rice in different locations (Rahimy et al., 2003, Egbe et al., 2010, Dhima et al., 2007).

Monitory advantage index was also evaluated to find out whether maize yield and the added common bean yield are profitable or not. The experimental locations were significantly different in production potential. The highest economic benefit was obtained from Guraferda as compared to Gimbo location (Table 5). Among the treatments the highest monitory advantage index was obtained from 1:1 maize-common bean intercropping at both locations. The highest benefit of 15,268.05 (Guraferda) and 13,695.90 ETB ha ${ }^{-1}$ (Gimbo) was also obtained from 1:1 maize-common bean intercropping. The results obtained from both locations were clearly indicated the economic advantages of intercropping over sole cropping. Ashoka et al. (2013) stated that the yield obtained from combination of the two component crops in the intercropping system was better than the sole yield of either of the two crops. The result is in line with the previous reports in grass-legume intercropping systems (Mahapatra, 2011). Likewise, Bhatnagar and Chaplot (1991) were also reported that a $55 \%$ increase in productivity for maize-legumes intercrop as compare to sole cropped maize. Workayehu and Wortmann (2011) also stated the agronomic as well as economic importance of intercropping due to maize with common bean intercropping.

Table 4. Land equivalent ratio (LER) and Monitory advantage index for intercropping of common bean with maize at Gimbo.

\begin{tabular}{|c|c|c|c|c|c|c|c|c|c|}
\hline $\begin{array}{l}\text { Row } \\
\text { ratio }\end{array}$ & $\begin{array}{l}\text { Compo- } \\
\text { nent } \\
\text { crop }\end{array}$ & $\begin{array}{l}\text { Intercrop } \\
\text { yield } \\
\left(\mathrm{kg} \mathrm{ha}^{-1}\right)\end{array}$ & $\begin{array}{l}\text { Pure stand } \\
\left(\mathrm{kg} \mathrm{ha}^{-1}\right)\end{array}$ & $\begin{array}{l}\text { LER } \\
\text { Maize }\end{array}$ & $\begin{array}{l}\text { LER } \\
\text { Bean }\end{array}$ & $\begin{array}{l}\text { Total } \\
\text { LER }\end{array}$ & $\begin{array}{l}\text { Intercrop } \\
\text { Gross } \\
\text { income } \\
\left(\mathrm{ETB} \mathrm{ha}^{-1}\right)\end{array}$ & $\begin{array}{l}\text { Sole crop } \\
\text { Gross } \\
\text { income } \\
\left(\mathrm{ETB} \mathrm{ha}^{-1}\right)\end{array}$ & $\begin{array}{l}\text { MAI } \\
\text { (ETB) }\end{array}$ \\
\hline \multirow[t]{2}{*}{$1: 1$} & Maize & 5015.4 & 5570.6 & 0.90 & & 1.52 & \multirow[t]{2}{*}{$37,723.80$} & $27,853.00$ & - \\
\hline & C bean & 2107.8 & 3407.2 & & 0.62 & & & $20,443.20$ & $13,695.90$ \\
\hline \multirow[t]{2}{*}{$1: 2$} & Maize & 4626.5 & 5570.6 & 0.83 & & 1.43 & \multirow[t]{2}{*}{$35,473 \cdot 90$} & $27,853.00$ & - \\
\hline & C bean & 2056.9 & 3407.2 & & 0.63 & & & $20,443.20$ & $11,505.05$ \\
\hline
\end{tabular}

$M A I=$ monitory advantage index $;$ LER = Land equivalent ratio; $1: 1=$ one maize and one common bean row intercropping; 1:2 = one maize and two common bean row intercropping.

Table 5. Land equivalent ratio (LER) and Monitory advantage index for intercropping of common bean with maize at Guraferda.

\begin{tabular}{|c|c|c|c|c|c|c|c|}
\hline $\begin{array}{l}\text { Row } \\
\text { ratio }\end{array}$ & $\begin{array}{c}\text { Component } \\
\text { crop }\end{array}$ & $\begin{array}{c}\text { Intercrop } \\
\text { yield } \\
\left(\mathrm{kg} \mathrm{ha}^{-1}\right)\end{array}$ & $\begin{array}{c}\text { Pure } \\
\text { stand } \\
\left(\mathrm{kg} \mathrm{ha}^{-1}\right)\end{array}$ & LER & $\begin{array}{c}\text { Intercrop } \\
\text { Gross income } \\
\left(\mathrm{ETB} \mathrm{ha}^{-1}\right)\end{array}$ & $\begin{array}{c}\text { Sole crop } \\
\text { Gross income } \\
\left(\mathrm{ETB} \mathrm{ha}^{-1}\right)\end{array}$ & $\begin{array}{l}\text { MAI } \\
\text { (ETB) }\end{array}$ \\
\hline \multirow[t]{2}{*}{$1: 1$} & Maize & 6353.9 & 6545.7 & 1.62 & \multirow[t]{2}{*}{$42,054.10$} & $32,728.50$ & - \\
\hline & C bean & 1714.1 & 2638.0 & - & & $15,828.00$ & $15,268.05$ \\
\hline \multirow[t]{2}{*}{$1: 2$} & Maize & 6158.2 & 6545.7 & 1.50 & \multirow[t]{2}{*}{$39,774.20$} & $32,728.50$ & - \\
\hline & C bean & 1497.2 & 2638.0 & - & & $15,828.00$ & $12,899.74$ \\
\hline
\end{tabular}

$M A I=$ monitory advantage index; LER = Land equivalent ratio; 1:1= one maize and one common bean row intercropping; 1:2 = one maize and two common bean row intercropping.

\section{Conclusion}

Sole cropped maize and common bean had significantly higher grain yield than intercropping. Conversely, the higher intercropping advantage and economic benefit was obtained in intercropping as compared to sole cropping. The combined yield advantage in terms of LER and economic benefit (MAI) was higher due to intercropping of 1:1 maize-common bean intercropping. Consequently, intercropping of one row of common bean with one row of maize (1:1) gave the highest land productivity of $62 \%$ at Guraferda and $52 \%$ at Gimbo location. Likewise, the higher economic benefits of 15,268.05 and 13,695.90 ETB ha-1 were also recorded when growing 1:1 maize-common bean intercropping at Guraferda and Gimbo location, respectively. Therefore, on the bases of the research results, growing 1:1 maize-common bean intercropping gave better agronomic as well as economic advantages. So, it could be suggested as an additional option to farmers in the study areas to increase land use efficiency and profit.

\section{Acknowledgments}

We are thankful to the Southern Agricultural Research Institute (SARI) and Bonga Agricultural Research Center for providing the research budget. We would like to thank the staff of Bonga Agricultural Research Center, particularly Ashenafi Abriham, Tesfaye Tarekegn, Demeke Lea and Aminat Hassen for their technical support and cooperation during the fieldwork. 


\section{References}

Amanullah, M.M., Vaiyapuri, K., Alagesan, A., Somasundaram, E., Sathyamoorthi, K. and Pazhanivelan, S. 2006. Effect of intercropping and organic manures on the yield and biological efficiency of cassava intercropping system (Manihot esculenta Crantz.). Res. J. Agric. Biol. Sci. 2(5): 201208.

Ashoka, P., Prabhakara Shetty, T.K., Sanjay, M.T. and Sunil, C.M. 2013. Effect of crop geometry and intercropping system on growth and yield of maize (Zea mays L.). Res. Crops. 14(2): 4.31-4.35.

Bhatnagar, G.S. and Chaplot, P.C. 1991. Evaluation of intercropping of winter maize with legumes. Int. J. Trop. Agric. 9(1): 5255 .

Dhima, K.V., Lithourgidis, A.A., Vasilakoglou, I.B. and Dordas, C.A. 2007. Competition indices of common vetch and cereal intercrops in two seeding ratio. Field Crop Res. 100: 249256. https://doi.org/10.1016/j.fcr.2006.07.008

Egbe, O.M., Alibo, S.E. and Nwueze, I. 2010. Evaluation of some extra-early-and earlymaturing cowpea varieties for intercropping with maize in southern Guinea Savanna of Nigeria. Agric. Biol. J. North America. 1(5): $845-858$.

https://doi.org/10.5251/abjna.2010.1.5.845.858

Emam, Y. 2003. Cereal Production, Tehran University Press, Iran. 188p.

EPPA, 2004. Ethiopian Pulse Proceedings of the workshop on food and forage legumes, 22-26 September 2003. Addis Ababa, Ethiopia.

Fujita, K. and Ofosu-Budu, K.G. 1996. Significance of intercropping in cropping systems. Dynamics of Roots and Nitrogen in Cropping Systems of the Semi-Arid Tropics. Japan Int. Res. Cen. Aqril. Sci. International Agricultural Series. 3: 19-40.

Gomez, A.A. and Gomez, K.A. 1983. Multiple cropping in the humid tropics of Asia. 248p.

IFPRI (International Food Policy Research Institute). 2010. Maize value chain potential in Ethiopia pulse export promotion agency). Available at www.ifpri.org/sites/ default/files/.../ethiopianagsectorwp_pulse.pdf. Accessed 30 July 2019.

Kurata, T. 1986. A study on the farming system in USSA. Quert. J. Agro. Eco. 26: 179-205.

Lithourgidis, A.S., Vlachostergios, D.N., Dordas, C.A. and Damalas, C.A. 2011. Dry matter yield, nitrogen content, and competition in pea-cereal intercropping systems. European J. Agron. 34(4): 287-294. https://doi.org/10.1016/j.eja.2011.02.007

Mahapatra, S. 2011. Study of grass-legume intercropping systems in terms of competition indices and monetary advantage index under acid lateritic soil of India. American J. Exp. Agric. 1(1): 1-6. https://doi.org/10.9734/AJEA/2011/001
Nasri, R., Kashani, A., Barary, M., Paknejad, F. and Vazan, S. 2014. Nitrogen uptake and utilization efficiency and the productivity of wheat in double cropping system under different rates of nitrogen. Int. J. Biosci. 4: 184-193. https://doi.org/10.12692/ijb/4.4.184-193

Negash, R. 2007. Determinants of adoption of improved haricot bean production package in Alaba Special Woreda, Southern Ethiopia. Thesis, Department of Rural Development and Agricultural Extension, School of Graduate Studies at Haramaya University, Ethiopia. 137p.

Nurbakhsh, F., Koocheki, A. and Mahallati, M.N. 2013. Evaluation of yield, yield components and different intercropping indices in mixed and row intercropping of sesame (Sesamum indicum L.) and bean (Phaseolus vulqaris L.). Int. J. Agric. Crop Sci. 5(17): 1958-1965.

Osagie, A.U. and Eka, O.U. (eds), 1998. Nutritional quality of plant foods postharvest research unit, University of Benin. 3441p.

Rahimy, M.M., Mazaheri, D., Khodabandeh, N. and Heidari, H. 2003. Assessment of product in corn and soybean intercropping in Arsanjan region. Agril. Sci. 9: 109-126.

SAS Institute. 2002-2010. The SAS system for windows. Release 9.3. Cary (NC): SAS Inst.

Seran, T.H. and Brintha, I. 2010. Review of maize based intercropping. J. Agron. 9(3): 135-145. https://doi.org/10.3923/ja.2010.135.145

Takim, F.O. 2012. Advantages of maize-cowpea intercropping over sole cropping through competition indices. J. Agric. Biodiv. Res. 1(4): 5.3-59.

Tamiru, H. 2014. Effect of intercrop row arrangement on maize and haricot bean productivity and the residual soil. World $J$. Agril. Sci. 2(4): 069-077.

Tsubo, M., Ogindo, H.O. and Walker, S. 2004. Yield evaluation of maize-bean intercropping in semi-arid region of South Africa. African Crop Sci. J. 12(4): 351-358.

https://doi.org/10.4314/acsi.v12i4.27897

Usmanikhail, M.U., Tunio, S.D., Jamro, G.H., Oad, F.C., Hassan, S.W., Chachar, Q.D., Khanzada, M.A. and Gandahi, A.W. 2012. Agronomic and economic effect of intercropping sugar beet with oilseeds and lentil. Pak. J. Bot. 44(6): 1983-1988.

Willey, R. 1979. Intercropping-its importance and research needs: Part 1. Competition and yield advantages. In: Field Crop Abstracts. 32: 1-10.

Willey, R.W. and Osiru, D.S.O. 1972. Studies on mixtures of dwarf sorghum and beans (Phaseolus vulgaris) with particular references to plant population. J. Agril. Sci. Cambridge. 79: 531-540.

https://doi.org/10.1017/Soo21859600025910

Workayehu, T. and Wortmann, C.S. 2011. Maizebean intercrop weed suppression and profitability in Southern Ethiopia. Agron. $J .103(4)$ : 1058-1063. https://doi.org/10.2134/agronj2010.0493 